\title{
Do financial institutions practice less tax avoidance than other companies?
}

\begin{abstract}
This paper examines whether financial institutions practice less tax avoidance than other companies. We hypothesize that financial institutions practice less tax avoidance than companies from other sectors. We predict and find that financial institutions have more GAAP effective tax rates (GAAP ETRs) and CASH effective tax rates (CASH ETR). For the purpose of this paper, we focused on all U.S. public firms. Our sample is composed by 110,030 firm-years from the Compustat database covering the period 2000-2018. We performed regressions with robust standard error and we find that, statistically, there is no difference between financial companies and companies from other sectors. One explanation for this result is that as financial companies have more reputational costs, they practice the same level of tax avoidance as companies in other sectors. However, when we perform sensitivity analysis by using Quantile Regression, we find that as the level of tax avoidance increases (quantiles), less financial companies practice tax avoidance. In 2002 the American government passed the federal Sarbanes-Oxley Act, which demanded more accountability, responsibility and transparency from the public companies. Thus, to verify the effects of this law on tax avoidance practices, we carried out additional analysis by using Propensity Score Matching (PMS). We conclude that this law enforced the public companies to be less aggressive in practicing tax avoidance. This topic has received little attention to date. Thus, this is one of the first papers to compare tax avoidance of financial and non-financial companies. This paper contributes both to tax avoidance literature and to literature on financial firms.
\end{abstract}

Keywords: Tax Avoidance; Financial Institutions; Sarbanes-Oxley Act. 


\section{INTRODUCTION}

We investigate whether the financial institutions practice less tax avoidance than companies from other sectors. Our hypothesis is that they do. This is because, in general, financial institutions are large companies. According to Zimmerman (1983), large firms are subjected to greater government scrutiny. Consequently, these companies have more reputational costs. Many studies about tax avoidance have been developed in the last years. So far, the results are mixed. Moreover, these studies have not analyzed financial companies. We extend this literature by examining tax avoidance in the context of financial companies and in the presence of high reputational costs.

Using 110,030 U.S. public firm-year observations from Compustat in the period 20002018, we show by performing regressions with robust standard error that, statistically, there is no difference in the level of tax avoidance of financial companies in comparison with companies from other sectors. This result holds both before and after we control for firm characteristics that are cross-sectionally associated with our tax avoidance measures: $R \& D$, leverage, foreign operations, size, intangibles, Property, Plant, and Equipment (PPE), ROA, and market-to-book (M/B). Including these controls ensures that the documented difference in tax avoidance between financial and non-financial companies is not driven by fundamentals. Our financial company variable also capture the difference between financial companies and non-financial companies in tax avoidance.

However, when we perform sensitivity analysis by using Quantile Regressions, we find that the higher the level of tax avoidance, the less financial companies aggressively practice tax avoidance. This is evidence that perhaps financial companies practice less tax avoidance than companies in other sectors. We also performed additional analysis for verifying the effects of the Sarbanes-Oxley Act by using Propensity Score Matching (PSM). We find that both from the point 
of view of GAAP ETR and from the point of view of CASH ETR, this law encouraged companies to be less aggressive in tax avoidance practices. Interestingly, we find that financial companies had a higher level of tax avoidance with the passage of this law.

Our paper contributes to the literature in several ways. First, our evidence provides an important step toward a better understanding the practices of tax avoidance of financial and nonfinancial companies. Many studies investigated tax avoidance from the agency theory perspective (Armstrong, Blouin, Jagolinzer, \& Larcker, 2015; Desai \& Dharmapala, 2008a; Khan, Srinivasan, $\&$ Tan, 2017). Other papers examined the link between tax avoidance and corporate governance (Desai \& Dharmapala, 2008b; Desai, Dyck, \& Zingales, 2007; Hoi, Wu, \& Zhang, 2013; Minnick \& Noga, 2010).

Some studies analyzed the link between tax avoidance and reputation (Frischmann, Shevlin, \& Wilson, 2008; Graham \& Tucker, 2006; Hanlon \& Slemrod, 2009; Rego, 2003; Shackelford and Shevlin, 2001). In general, these studies examined the CEO level. The traditional perspective is that reputational costs are an important aspect that limit CEOs and firms from to engage in tax avoidance. Generally, the studies in tax avoidance focus on non-financial institutions. However, the financial crisis of 2007-2009 shows us that it is very important to study the financial institutions (Gallemore, Gipper, \& Maydew, 2019; Lobo, 2017; Walter, 2016).

Secondly, this paper contributes to the literature on tax avoidance and on financial institutions. The previous studies suggest that the companies do not engage in tax avoidance because of reputational concerns. However, the empirical evidence about this is scarce (Chyz \& Gaertner, 2018). Basically, the previous studies focus on non-financial companies. Thus, there is no existing study that shows financial institutions practice less tax avoidance than other companies. Our study adds to the literature by examining whether the financial institutions practice less tax 
avoidance. We also contribute to the literature by analyzing the data after the passing of the federal Sarbanes-Oxley Act in 2002 through which we can verify the government's enforcement through the Internal Revenue Service (IRS). Finally, we are answering the call in Hanlon and Heitzman (2010) to study tax avoidance in financial institutions.

The rest of the paper proceeds as follows. In the next section we review related literature; Section 3 presents our hypothesis; Section 4 describes our sample and research design; Section 5 presents Primary empirical analyses; and Section 6 concludes.

\section{LITERATURE REVIEW}

Tax avoidance is a topic that has received the attention both of researchers and practitioners in the last decades. The main point is that taxes represent a significant cost to the companies by reducing cash flows available to the firm and shareholders. Thus, it is intuitive that companies and shareholders have incentives to reduce taxes through tax avoidance activities. However, this intuition did not consider the reputational costs. When reputational costs are factored in, when deciding to practice aggressive tax avoidance, companies need to consider the impacts on their reputation. Research that investigated tax avoidance focused on: a) agency theory; b) corporate governance and c) reputation, more sparingly. Basically, the researchers analyzed the setting without focusing on financial companies. Thus, this paper will help to fill this gap in the literature.

\subsection{Tax avoidance and Agency theory}

Many studies investigated tax avoidance from the agency theory perspective. Slemrod (2004) offered an economics perspective on corporate tax noncompliance. He addressed the supply of corporate noncompliance and the demand for corporate tax noncompliance, focusing on how 
the standard Allingham-Sandmo approach needs to be modified when applied to public corporations. He addressed policy proposals aimed at increased disclosure of corporate tax activities to both the IRS and to the public.

Focusedly on another aspect of this issue, Chen \& Chu (2005) offered a formal model of corporate income tax evasion. They showed that while individual tax evasion is essentially a portfolio-selection problem, corporate income tax evasion is much more complicated. For example, when the owner of a firm decides to evade taxes, not only does she risk being detected by the tax authorities, more importantly, the optimal compensation scheme offered to the employees will also be altered. They highlighted that due to the illegal nature of tax evasion, the contract offered to the manager is necessarily incomplete. Thus, this creates a distortion in the manager's effort and reduces the efficiency of the contract. Tax evasion thus increases the profit retained by the firm not only at the risk of being detected, but also at the cost of efficiency loss in internal control.

Crocker \& Slemrod (2005), on the other hand, examined corporate tax evasion in the context of the contractual relationship between the shareholders of a firm and a tax manager who possesses private information regarding the extent of legally permissible reductions in taxable income, and who may also undertake illegal tax evasion. They used a costly state falsification framework. Thus, they formally characterize the optimal incentive compensation contract for the tax manager and, in particular, how the form of that contract changes in response to alternative enforcement policies imposed by the taxing authority. According Crocker \& Slemrod (2005), the optimal contract may adjust to offset, at least partially, the effect of sanctions against illegal evasion. 
From the perspective of outcomes of tax avoidance, Desai \& Dharmapala (2008a) predicted that the effect of tax avoidance on firm value should vary systematically with the strength of firm governance institutions. The empirical results indicate that the average effect of tax avoidance on firm value is not significant. However, the effect is positive for well-governed firms as predicted. Coefficient estimates are consistent with an expected life of five years for the devices that generate these tax savings for well-governed firms. Alternative explanations for the dependence of the valuation of the tax avoidance measure on firm governance do not appear to be consistent with the empirical results. The findings indicate that the simple view of corporate tax avoidance as a transfer of resources from the state to shareholders is incomplete, given the agency problems characterizing shareholder-manager relations.

Expanding this analysis, Armstrong et al. (2015) examined the link between corporate governance, managerial incentives, and corporate tax avoidance. Second, they suggest that similar to other investment opportunities that involve risky expected cash flows, unresolved agency problems may lead managers to engage in more or less corporate tax avoidance than shareholders would otherwise prefer. They find no relation between various corporate governance mechanisms and tax avoidance at the conditional mean and median of the tax avoidance distribution. However, using Quantile Regression, they find a positive relation between board independence and financial sophistication for low levels of tax avoidance, but a negative relation for high levels of tax avoidance. Thus, these results indicate that these governance attributes have a stronger relation with more extreme levels of tax avoidance, which are more likely to be symptomatic of over- and under-investment by managers.

Finally, Khan et al. (2017) provided new evidence on the agency theory of corporate tax avoidance by showing that increases in institutional ownership are associated with increases in tax 
avoidance. They find a significant and discontinuous increase in tax avoidance. The tax avoidance involves the use of tax shelters, and immediate benefits include higher profit margins and likelihood of meeting or beating analyst expectations. Collectively, the results shed light on the effect of increased ownership concentration on tax avoidance.

\subsection{Tax avoidance and Corporate governance}

Other studies have investigated the link between tax avoidance and corporate governance. For example, Desai et al. (2007) analyzed the interaction between corporate taxes and corporate governance. They show that the design of the corporate tax system affects the amount of private benefits extracted by company insiders, and that the quality of the corporate governance system affects the sensitivity of tax revenues to tax changes.

Relatedly, Desai \& Dharmapala, (2008a) reviwed emerging literature that explores how agency problems create such interactions and provides evidence on their importance. According to them, this literature has neglected how taxation can interact with the various mechanisms that have arisen to improve the corporate governance problem, such as concentrated ownership, accounting and information systems, high-powered incentives, financing choices, payout policy, and the market for corporate control.

Minnick \& Noga (2010), on the other hand, focus their research on executive and director compensation and show that incentive compensation provides long-term incentives to improve performance by establishing a link between higher pay-performance sensitivity and lower taxes. They find that incentive compensation drives managers to make investments into longer-horizon pay outs such as tax management. Furthermore, they find that this investment into tax management benefits shareholders; better tax management is positively related to higher returns to shareholders. 
Finally, Hoi et al. (2013) examined the empirical association between corporate social responsibility (CSR) and tax avoidance. Their findings suggest that firms with excessive irresponsible CSR activities have a higher likelihood of engaging in tax-sheltering activities and greater discretionary/permanent book-tax differences. Moreover, at the beginning of the Financial Accounting Standards Board (FASB) Interpretation No. 48, these firms have more uncertain tax positions; also, these firms' initial tax positions are likely supported by weaker facts and circumstances as indicated by their larger post-FIN 48 settlements with tax authorities and their higher likelihood of a net decrease in the overall level of uncertain tax positions after FIN 48. Collectively, their results suggest that firms with excessive irresponsible CSR activities are more aggressive in avoiding taxes, lending credence to the idea that corporate culture affects tax avoidance.

\subsection{Tax avoidance and reputation}

Other studies analyzed the connection between tax avoidance and reputation. In general, these studies examined the CEO level. Dyreng, Hanlon, \& Maydew (2010) investigated whether individual top executives have incremental effects on their firms' tax avoidance that cannot be explained by characteristics of the firm. To identify executive effects on firms' effective tax rates, they construct a dataset that accompanies the movement of 908 executives across firms over time. Their results indicate that individual executives play a significant role in determining the level of tax avoidance that companies commit. They conclude that the economic magnitude of the executive effects on tax avoidance is large.

Rego \& Wilson (2012) examine this issue from perspective of equity risk incentives as another determinant of corporate tax aggressiveness. Aggressive tax strategies involve significant 
uncertainty and can impose costs on both firms and managers. As a result, managers must be incentivized to engage in risky tax avoidance that is expected to generate net benefits for the firm and its shareholders. They predict that equity risk incentives motivate managers to engage risky tax strategies. Consistent with this prediction, they find that larger equity risk incentives are associated with greater tax risk and the magnitude of this effect is economically significant. Their results are robust across four measures of tax risk. Thus, they accomplish that equity risk incentives are a significant determinant of corporate tax aggressiveness.

Similarly, Chyz (2013) investigates whether executives who evidence a propensity for personal tax evasion (suspect executives) are associated with tax sheltering at the firm level. His results indicate that the presence of suspect executives is positively associated with proxies for corporate tax sheltering. Moreover, firm-years with suspect executive presence have significantly higher cash tax savings relative to firm-years without suspect executive presence.

Gaertner (2014) examines the association between CEOs' after-tax incentives and their firms' level of tax avoidance. Economic theory holds that firms should compensate CEOs on an after-tax basis when the expected tax savings generated from additional incentive alignment overcomes the incremental compensation demanded by CEOs for supporting additional taxes compensation risk. Using hand-collected data from proxy statements, he finds a negative relation between the use of after-tax incentives and effective tax rates. Moreover, he finds a positive association between the use of after-tax incentives and CEO cash compensation, suggesting that CEOs who are compensated on an after-tax basis demand a premium for bearing additional risk.

Gallemore, Maydew, \& Thornock (2014) investigate whether firms and their top executives bear reputational costs from engaging in aggressive tax avoidance activities. They employ a database of 118 firms that were subject to public scrutiny for having engaged in tax 
shelters, representing the largest sample of publicly identified corporate tax shelters analyzed to date. They examine the reputational costs that prior research has shown that firms and managers face in cases of alleged misconduct: increased CEO and CFO turnover, auditor turnover, lost sales, increased advertising costs, and decreased media reputation. They find little evidence that firms or their top executives support significant reputational costs as a result of being accused of engaging in tax shelter activities. Furthermore, they find no decrease in firms' tax avoidance activities after being accused of tax shelter activity. Overall, they conclude that there is little evidence of tax shelter usage leading to reputational costs at the firm level.

Addressing the problem from another angle, Chyz and Gaertner (2018) examine the effect of corporate tax outcomes on forced CEO turnover. While prior research argues that firms often do not engage in tax avoidance due to reputational concerns, the empirical evidence suggesting the existence of reputational costs is scarce. In a broad sample of firms, they find evidence of a relation between the payment of low taxes and forced turnover. They also find that forced CEO turnover is more likely when the firm pays a high tax rate. Their results are consistent with the existence of previously unexplored individual reputational costs for not engaging in tax avoidance.

Finally, Lanis, Richardson, Liu, and McClure (2018) examine the impact of corporate tax avoidance on the reputation of the board of directors and chief executive officer (CEO). Their regression results show that when firms engage in tax avoidance, both directors and CEOs, on average, are rewarded by improvements in their reputations as proxied by an increased number of outside board seats. In particular, both independent directors and non-CEO executive directors suffer positive changes in reputation. Thus, they provide important empirical evidence confirming an association between tax avoidance and the individual reputations of directors and CEOs. 


\section{HYPOTHESIS DEVELOPMENT}

Generally, prior literature focused on non-financial institutions. However, the financial crisis of 2007-2009 shows the relevance to study the banking sector (Gallemore et al., 2019; Walter, 2016). By trying to define reputational risk and to outline the sources of such risk facing large international banks, Walter (2016) considers the key drivers of reputational risk in the presence of transaction costs and imperfect information, and surveys available empirical research on the impact of reputational losses imposed on banks.

According to Gallemore et al. (2019), banks have played an important role in facilitating the tax planning of their client companies. The authors find that a client's own tax planning is strongly associated with the average tax planning of the bank's other customers. Their results suggest that while banks are financial intermediaries, they also act as tax planning intermediaries. In addition, the authors find that bank loans are essential tools in the tax avoidance process.

Our hypothesis is based on the idea that financial institutions practice less tax avoidance than other companies because in general, financial companies are large and they are the focus of attention of both society and government. Thus, financial companies may have more reputational costs for practicing tax avoidance. For instance, in February, 2015 The Guardian ${ }^{l}$ reported that the HSBC scandal about the systematic aiding of tax avoidance caused horrible damage to its reputation. Thus, our hypothesis is:

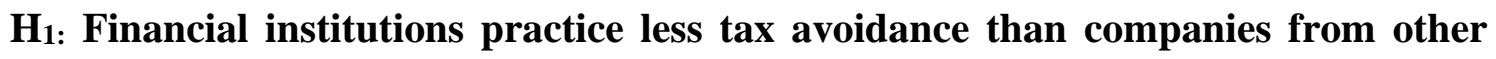
sectors.

\footnotetext{
${ }^{1}$ https://www.theguardian.com/business/2015/feb/25/hsbc-scandal-horrible-damage-reputation-chairman. Accessed in February, 2019.
} 


\section{SAMPLE AND RESEARCH DESIGN}

\subsection{Sample}

We focus on all U.S. public firms. Financial accounting data were collected from Compustat. Our sample consists of 110,030 firm-years in the Compustat covering the period 2000-2018. Table 1 Panel A reports our sample composition after exclusions. Panel B of Table 1 tabulates the distribution of observations by year. Of the 110,030 firm-year observations in the Compustat, over $7.60 \%$ are financial-firm observations, and $92.54 \%$ are non-financial-firm that comprise our sample. Panel C presents the industry distribution of the sample. The sectors with more observations are Manufacturing (38.8\%), Mining, Quarrying, and Oil and Gas Extraction (13.6\%), and Information (10.9\%). Finance sector represents $7.5 \%$ of our sample. Prior literature shows cross-industry variation in firms' effective tax rate. Thus, we cluster for industry and year effects.

\subsection{Research design}

We use two measures of tax avoidance in our analyses. Following, we discuss each measure. For easy reading, we present the definitions of these variables in the Appendix A. We compare two groups of companies: financial and non-financial. In the United States there is a federal law, the Sarbanes-Oxley Act of 2002, which requires more transparency from financial institutions. This law is known as the "Public Company Accounting Reform and Investor Protection Law" (in the Senate) and "Corporate and Audit Responsibility and Responsibility Law", and more commonly called Sarbanes - Oxley, Sarbox or SOX. Beginning in 2002, the Internal 
Revenue Service (IRS) increased scrutiny of aggressive tax positions and legislation that led to an increase in regulatory scrutiny about the tax function.

To examine our hypothesis, we use the measure of tax avoidance Effective Tax Rates. Following Hanlon and Heitzman (2010), this study defines tax avoidance very broadly. Thus, tax avoidance represents a continuum of tax planning strategies. We use two measures of tax avoidance, GAAP ETR and CASH ETR, to capture this continuum of activities in order to fully exploit the potential positive or negative reputation effects associated with each level of tax avoidance. According to Hanlon and Heitzman (2010), GAAP ETR is defined as total income tax expense divided by accounting profit before taxes.

Thus, this measure is a total income tax expense. A tax strategy that defers taxes (for example, faster depreciation for tax purposes) will not change the GAAP ETR. In addition, several items that are not tax planning strategies, such as changes in the valuation allowance or changes in the reserve for tax contingencies, may affect the GAAP ETR. On the other hand, CASH ETR is calculated using cash taxes paid in the numerator and is affected by tax deferral strategies, but is not affected by changes in the accruals of tax accounting. Some studies show that there is substantial variation in effective tax rates (Blouin, 2014; Dyreng et al., 2010). The choice of this setting is powerful because this sample (Financial institutions and non-financial) has enough exogeneity variation in the reputational costs of the companies.

The first measure the we use is GAAP ETR. According to Chen, Chen, Cheng, and Shevlin (2010) this measure reflects aggressive tax planning through permanent book-tax differences. Basically, the objective of GAAP is to capture the economics of transactions in order to provide useful information for decision makers (Hanlon \& Heitzman, 2010). 


$$
\text { GAAP ETR } \frac{\text { Total income tax expense }(\text { TXT) }}{\text { Pre - tax book income (PI) before special items(SPI) }}
$$

The second measure we use is the cash effective tax rate (CASH ETR). This measure is calculated using cash taxes paid in the numerator, and is affected by tax deferral strategies but is not affected by changes in the tax accounting accruals. According to Hanlon and Heitzman (2010), the annual CASH ETR could mismatch the numerator and denominator if the cash taxes paid includes taxes paid on earnings in a different period (e.g., from an IRS audit completed in the current year) while the denominator includes only current period earnings.

$$
\text { Cash ETR } \frac{\text { Cash tax paid (TXPD) }}{\text { Pre - tax book income (PI)before special items (SPI) }}
$$

To test our hypothesis, we estimate the following cross-sectional regression and we use control variables used in previous studies such as Leverage, Foreign Operations, Size, Intangibles, Gross PPE, and Market-to-Book.

$$
\begin{aligned}
\text { TaxAvoid }_{i, t}= & \alpha_{0}+\beta_{1} \text { Finance }_{i, t}+\beta_{2} R \& D_{i, t}+\beta_{3} \text { Leverage }_{i, t}+\beta_{4} \text { Foreign Operations }_{i, t} \\
& +\beta_{5} \text { Size }_{i, t}+\beta_{6} \text { NOL }_{i, t}+\beta_{7} \text { Intangibles }_{i, t}+\beta_{8} \text { Gross PPE }_{i, t}+\beta_{9} R O A_{i, t} \\
& +\beta_{10} \text { Market } \text { to }- \text { Book }_{i, t}+\varepsilon_{i, t}
\end{aligned}
$$

Where TaxAvoid $_{i, t}$ is the tax avoidance measure as discussed above; Finance $_{i, t}$ is measured as (1) an indicator variable coded as one for financial firms, zero otherwise; (2) $R \& D_{i, t}$ is calculated as Research and development expense (XRD) divided by net sales (SALE); when missing, reset to 0 ; (3) Leverage $e_{i, t}$ is defined as the sum of long-term debt (DLTT) and long-term 
debt in current liabilities (DLC) divided by total assets (AT); (4) Foreign Operations $s_{i, t}$ is calculated in the following way: the firm has a non-missing, non-zero value for pre-tax income from foreign operations (PIFO); (5) Size $_{i, t}$ is the natural log of total assets (AT); (6) $N O L_{i, t}$ is an indicator if the firm has a non-missing value of tax loss carry-forward (TLCF); (7) Intangibles $_{i, t}$ is the ratio of intangible assets (INTANG) to total assets (AT); (8) Gross $P P E_{i, t}$ is Gross property, plant, and equipment (PPE GT) divided by total assets (AT); (9) $R O A_{i, t}$ is Operating income before depreciation (OIBDP) scaled by total assets (AT); and (10) Market - to - Book $_{i, t}$ is measured as market value of equity (PRCC_F x CSHO) scaled by book value of equity (CEQ). Continuous variables are winsorized at the $2.5 \%$ and $97.5 \%$ levels.

Whether financial firms are less tax aggressive than non-financial firms, we expect a positive coefficient on the Financial variable, $\beta_{1}$. We expect opposite signs if financial firms are more tax aggressive. We control for firm characteristics reported in prior literature (Atwood, Drake, Myers, \& Myers, 2012; Cen, Maydew, Zhang, \& Zuo, 2017; S. Chen et al., 2010; James A. Chyz, 2013; Dyreng, Hanlon, \& Maydew, 2008; Dyreng et al., 2010; Gallemore et al., 2019; Lanis et al., 2018)

that are correlated with our tax avoidance measures so as to ensure that our results are not driven by fundamental differences between financial and non-financial firms.

\section{EMPIRICAL ANALYSES}

\subsection{Primary empirical analyses}

Table 3 presents the descriptive statistics for the variables used in our analyses. Both the mean of GAAP ETR and the mean of C|ASH ETR is $14 \%$. The average firm has R\&D of 0.32, a leverage ratio of 0.19 , average size of $\$ 5.64$ million, average Net Operating Loss of 0.7 , a tangible 
asset ratio of 0.14 . Further, the average firm in our sample has Gross PPE to total assets of 0.50, average ROA of 0.02 . Thus, average firm is not profitable. Finally, average firm in our sample has Market to Book of 3.76.

Table 3 presents Pearson and Spearman correlations for the regression variables used in this paper. GAAP ETR variable has a significant positive relation with Finance variable (0.0089*). However, the magnitude of this relation is not high. But by considering Cash ETR this coefficient has more magnitude $\left(0.0203^{*}\right)$. R\&D presents a significant and negative relation $\left(-0.0412^{*}\right)$ with GAAP ETR. This relation continues by analyzing CASH ETR $\left(-0.0419^{*}\right)$. Thus, this indicates that firms that practice less tax avoidance invest less in research and development. Leverage has a significant and positive relation $\left(0.0213^{*}\right)$ with GAAP ETR and a significant and negative relation (-0.0094) with CASH ETR.

Foreign Operations presents a significant and positive relation both with GAAP ETR $\left(0.0228^{*}\right)$ and with CASH ETR $\left(0.0522^{*}\right)$. Thus, we can infer that firms that practice less tax avoidance have more pre-tax income from foreign operations. Size has a significant and positive relation both with GAAP ETR $\left(0.1141^{*}\right)$ and with CASH ETR $\left(0.1236^{*}\right)$. These results indicate that firms that practice less tax avoidance are larger. NOL (Net Operating Loss) has a negative, but no significance with GAAP ETR (-0.0055). However, by considering CASH ETR this coefficient is positive and significant $\left(0.0187^{*}\right)$. We can infer that from perspective of CASH ETR, firms less aggressive in tax avoidance have more tax loss carry-forward.

Finally, Intangibles variable has a significant and positive relation both with GAAP ETR $\left(0.0177^{*}\right)$ and with CASH ETR $\left(0.0456^{*}\right)$. So, these results indicate that firms less aggressive have more intangibles to total assets. PPE (Property, plant, and equipment) variable presents a positive and significant relation with GAAP ETR $\left(0.0314^{*}\right)$ and a significant, but negative relation with 
Cash ETR $(-0.0165 *)$. ROA presents a significant and positive relation both with GAAP ETR $(0.1215 *)$ and with CASH ETR $(0.1612 *)$. We infer firms that practice less tax avoidance are more profitable. Market-to-Book have a significant and positive relation both with GAAP ETR $(-0.0263 *)$ and with Cash ETR $(-0.0263 *)$.

Table 4 reports the difference of means between financial and non-financial companies. The results indicate that financial exhibit significantly lower tax avoidance than non-financial firms both from the perspective of the GAAP ETR and CASH ETR. The differences of means are significantly different from zero. The GAAP ETR present a difference of means of -0.017 with the significance of 5\%, and CASH ETR shows a difference of means of -0.029 with the significance of $1 \%$. Thus, these results are the first evidence that maybe financial companies practice less tax avoidance than companies from the other sectors. However, we performed other methods to validate them.

Table 5 presents our primary results regarding the relation between financial firms and tax avoidance. We estimate Equation (1) using ordinary least squares (OLS). We adjust the standard errors for heteroskedasticity, serial and cross-sectional correlation using a twodimensional cluster at the firm and year level. According to (Petersen, 22AD), this technique is the preferred method for estimating standard errors in corporate finance applications using panel data.

OLS estimates of the conditional mean of tax avoidance presented in Table 5 provide no evidence of a relation between Financial variable and tax avoidance. In the regression with GAAP ETR, the coefficient of Financial is zero (0.000) and not significant. By using CASH ETR, the coefficient is 0.008 , but also not significant. Thus, we do not have evidence that financial firms 
practice less tax avoidance. An explanation for this result is that assuming that financial companies have a higher reputational cost, this makes them less aggressive by practicing tax avoidance.

Contrary to prior research that finds a positive relation between $\mathbf{R} \& \mathbf{D}$ (research and development) expenditures and tax avoidance ( Dyreng et al., 2008; Atwood et al., 2012) that find no association between tax avoidance and R\&D in their models, we find negative association between tax avoidance and research and development (R\&D) in our models (GAAP ETR and CASH ETR). Unlike prior research that find a positive association between tax avoidance and Leverage (Dyreng et al., 2008; Atwood et al., 2012), we find a negative and significant relation between leverage and tax avoidance (GAAP ETR and Cash ETR).

In relation to Foreign Operations, previous results are inconclusive. For example, Rego (2003) and Atwood et al. (2012) find that multinationals engage in less tax avoidance than domestic firms. On the other hand, Wilson (2009) finds that firms with foreign income are more likely to be tax-shelter participants. Our results are more consistent with those find in Armstrong et al., (2015); Rego (2003). We find a coefficient negative and significant to the Foreign Operations variable.

On the contrary of Rego (2003) that finds a relation positive and significant between Size and tax avoidance, we find a positive and significant relation between size and GAAP ETR and CASH ETR. Thus, we find that large firms practice less tax avoidance. We find inconclusive results when we analyze the relation of NOL with our two measures of tax avoidance. We find a coefficient negative, but not significant between NOL and GAAP ETR. On the other hand, we find a positive and significant relation between NOL and CASH. 
Regarding to Intangibles our results are not conclusive. To analyze the relation between intangibles and GAAP ETR we find a coefficient positive, but not significant. However, by using CASH ETR we find a positive and significant relation between CASH ETR and Intangibles.

With respect to Property, plant, and equipment (PPE), our results are also not conclusive. We find a positive and significant coefficient between PPE and GAAP ETR. However, similar to Cen et al. (2017) we find a negative and significant relation between PPE and Cash ETR. Concerning profitability, we find a positive and significant coefficient between ROA and GAAP ETR and Cash ETR. These results suggest that large firms practice less tax avoidance. This result is contrary to that find in previous research (Rego, 2003; Wilson, 2009). Finally, we find mixed results between Market to Book and our two tax avoidance measures.

\subsection{Sensitivity analysis}

In this section, we explore whether the level of tax avoidance differs among the quantiles. For this, we performed Quantile Regression. The method of OLS regression considers the least squares minimization method to estimate its parameters, while the Quantile Regression uses the minimization of weighted absolute errors. This method minimizes the effects of outliers, and when data do not have normal distribution (assumption for regression), it presents better results when estimating the central position of the distribution (Clout, Falta, \& Willett, 2015; Koenker, 2004; Koenker, Bassett, \& Jan, 2007).

According to the Table 6, we can see that in the Quantile 0.10 financial institutions practice more tax avoidance by the measure GAAP ETR than other companies. However, in the Quantile 0.50 and 0.90 they perform less GAAP ETR than other companies. Thus, as the level of GAAP ETR increases, less financial companies practice tax avoidance. On the other hand, we can 
infer that as the level of GAAP ETR increases, non-financial companies practice more tax avoidance. In other words, financial companies are less aggressive when they practice tax avoidance. From the perspective of CASH ETR, the results show that the tax avoidance practices in the Quantile 0.10 and Quantile 0.90 are statistically significant. However, in the Quantile 0.50 we find that financial companies practice more tax avoidance. These results are important because they shed light in one problem that is not explored by the literature.

\subsection{Additional analysis}

One of the problems in analyzing causal effects in social sciences is endogeneity. Sometimes, it is not easy to have the equivalence of distribution between the control and treated groups. Basically, endogeneity occurs when predictor $\mathrm{T}$ correlates with error term. Many studies have showed that the endogeneity is a big issue for researchers because its biasing effects (Hamilton, B. H., \& Nickerson, 2003; Li, 2012).

To addressing endogeneity, we use the Propensity Score Method - PSM (Li, 2012). The definition of a propensity score is the probability of study participants receiving a treatment based on observed characteristics. Thus, the PSM refers to a special procedure that uses propensity scores and matching algorithm to calculate the causal effect. Shipman, Swanquist, \& Whited (2017) did a survey about the use of Propensity Score Matching in accounting research. They show that this method has been very used to solve many problems in accounting.

In this paper, we verified the effects of the Sarbanes-Oxley Act (SOX), exogenous shock, are different in financial and non-financial companies. After series of corporate failures and accounting scandals that started with the Enron and the subsequent Andersen collapse, the U.S. Congress passed the Sarbanes-Oxley Act (SOX) in July 2002. 
This act required that companies have more effective internal controls over financial reporting and to provide periodic-attested evaluations of internal controls effectiveness. Thus, we predict that after this act both financial and non-financial companies reduced their tax avoidance level. The objective here is to analyze whether with the passage of the Sarbanes-Oxley Act in 2002, a period when firms were under relatively more pressure, they practice less tax avoidance. For this purpose, we use a dummy variable where is equal to 1 if the year is in the period from 2002 to 2018 , and equal to zero otherwise.

From the perspective of GAAP ETR, Table 7 presents the results from the first-stage prediction model of Propensity Score Matching, probit regression. We can see that the law Sarbanes-Oxley Act (SOX) was passed, the likelihood of companies having greater GAAP ETR was negative. Thus, during this period, the companies reduced in $10.80 \%$ the likelihood to be aggressive by practicing tax avoidance. Interestingly, financial companies became more aggressive in their practices of tax avoidance. They increased in $19.5 \%$ the level of tax avoidance with passing the SOX.

Table 8 presents the composition of the sample of the PSM. In the Table 9, we can see the results of PSM by examining the effects of the SOX on GAAP ETR of all companies of our sample. We matched considering 01 neighbor, 05 neighbors and 10 neighbors. In all of them we find negative result for the average treatment effect among treated (ATT). Thus, we can infer that the SOX enforced the public American companies practice less tax avoidance. Figure 1 shows the result of PSM (GAAP ETR). Figure 02 exhibits the sample before the matching and Figure 03 presents the sample after the matching.

On the other hand, from the perspective of CASH ETR, Table 10 Table 7 shows the results from the first-stage prediction model of Propensity Score Matching, probit regression. We find 
that with the SOX, public companies reduced in $10.50 \%$ the odd of practicing tax avoidance (CASH ETR). However, when we focus on financial companies, we find that they increased in $11.40 \%$ the odd to be more aggressive by practicing tax avoidance. Table 11 presents the sample composition of PSM (CASH ETR).

Table 12 exhibits the results of matching in 01 neighbor, 05 neighbors and 10 neighbors. Curiously, we find in all of them positive result for the average treatment effect among treated (ATT). So, when we analyze the tax avoidance practices from the perspective of CASH ETR, we find that during the period that the SOX was passed, public American companies had greater CASH ETR. Figure 04 presents the PSM graph. Figure 05 shows the sample before matching and Figure 06 exhibits the sample after matching.

The results that we present in this paper are a starting point to better understand the differences in the practice of tax avoidance between financial and non-financial companies. To date, we have not identified any other papers that have set out to investigate this. Thus, we encourage more empirical research to be carried out in order to better understand whether financial companies practice less tax avoidance than companies in other sectors, something not yet explored in the literature.

\section{CONCLUSION}

We examine whether financial companies practice less tax avoidance the companies from other sectors. For this purpose, we use two measures to capture tax avoidance (GAAP ETR and CASH ETR). Our sample was composed by all U.S. public firms. Our sample consists of 110,030 firm-years in the Compustat covering the period 2000-2018. We performed some methods to clarify this question. First, we performed regressions with robust standard error. We find that, statistically, there is no difference in the level of tax avoidance of financial companies in 
comparison with companies from other sectors. One explanation for this result is that financial companies have greater reputational cost. Thus, it can inhibit them from being aggressive in tax avoidance practices.

To validate this result, we performed Quantile regressions (0.10, 0.50 and 0.90 quantis). From the perspective of GAAP ETR, we find that in the 0.10 quantil, financial companies are more aggressive than other companies. However, as the level of tax avoidance increases, financial companies become less aggressive. When we focus on CASH ETR, we only find statistical significance in 0.50 quantil with coefficient positive. A reason for that, is the fact GAAP ETR and CASH ETR capture different aspects of the tax avoidance.

We also do additional analysis to verify the effect of the passage Sarbanes-Oxley Act (SOX). Given that this law requires more responsibility, accountability and transparency, we expect that it has encouraged companies to be less aggressive in the practice of tax avoidance. To examine it, we use Propensity Score Matching (PSM). From the view of GAAP ETR, we find in the probit regression that the level of GAAP ETR reduced the likelihood of public companies in the U.S. being more aggressive in terms of GAAP ETR has reduced by $10.80 \%$. However, when we focus on financial companies, we find that they increased the likelihood being more aggressive by practicing tax avoidance by $19.50 \%$. The results of PSM show that in the period of 2002 to 2018 (period that the SOX passed), the level of GAAP ETR reduced.

When we perform PSM using the measure CASH ETR, we find curious results. In the first-stage, we use probit regression. We find that even though companies, in general, decreased the level of CASH ETR, financial companies presented a higher level of CASH ETR with the passage of SOX. When we do the PSM, we find that the level of CASH ETR increased with the passage of SOX. 
To date, we have not identified any other papers that have set out to analyze whether the level of tax avoidance differs between financial and non-financial companies. Thus, although our results are inconclusive, they are a starting point for further empirical research to be carried out and this point not yet addressed in the literature is clarified.

Our paper contributes to the literature in different ways. First, our evidence provides an important step toward a better understanding the practices of tax avoidance of financial and nonfinancial companies. Secondly, this paper contributes to the literature on tax avoidance and on financial institutions. We also contribute to the literature by analyzing the effects of the passing of the federal Sarbanes-Oxley Act in 2002. Finally, we are answering the call in Hanlon and Heitzman (2010) to study tax avoidance in financial institutions.

\section{REFERENCES}

Armstrong, C. S., Blouin, J. L., Jagolinzer, A. D., \& Larcker, D. F. (2015). Corporate governance, incentives, and tax avoidance. Journal of Accounting and Economics, 60(1), 117. https://doi.org/10.1016/j.jacceco.2015.02.003

Atwood, T. J., Drake, M. S., Myers, J. N., \& Myers, L. A. (2012). Home country tax system characteristics and corporate tax avoidance: International evidence. Accounting Review, 87(6), 1831-1860. https://doi.org/10.2308/accr-50222

Blouin, J. (2014). Defining and Measuring Tax Planning Aggressiveness. National Tax Journal, 67(4), 875-900. https://doi.org/10.17310/ntj.2014.4.06

Cen, L., Maydew, E. L., Zhang, L., \& Zuo, L. (2017). Customer-supplier relationships and corporate tax avoidance. Journal of Financial Economics, 123(2), 377-394. https://doi.org/10.1016/j.jfineco.2016.09.009

Chen, K.-P., \& Chu, C. Y. C. (2005). Internal control vs. external manipulation: A model of corporate income tax evasion. RAND Journal of Economics, 36(1), 151-164.

Chen, S., Chen, X., Cheng, Q., \& Shevlin, T. (2010). Are family firms more tax aggressive than non-family firms? Journal of Financial Economics, 95(1), 41-61. https://doi.org/10.1016/j.jfineco.2009.02.003

Chyz, J. A, \& Gaertner, F. B. (2018). Can paying "too much" or "too little" tax contribute to forced CEO turnover? Accounting Review, 93(1), 103-130. https://doi.org/10.2308/accr51767

Chyz, James A. (2013). Personally tax aggressive executives and corporate tax sheltering. Journal of Accounting and Economics, 56(2-3), 311-328. https://doi.org/10.1016/j.jacceco.2013.09.003 
Clout, V., Falta, M., \& Willett, R. J. (2015). Fundamental relations between market and accounting values Fundamental relations between market and accounting values. Working Paper, (February).

Crocker, K. J., \& Slemrod, J. (2005). Corporate tax evasion with agency costs. Journal of Public Economics, 89(9-10), 1593-1610. https://doi.org/10.1016/j.jpubeco.2004.08.003

Desai, M. A., \& Dharmapala, D. (2008a). Corporate tax avoidance and firm value. The Review of Economics and Statistics, 91(3), 537-546.

Desai, M. A., \& Dharmapala, D. (2008b). Tax and Corporate Governance: An Economic Approach (Vol. 3).

Desai, M. A., Dyck, A., \& Zingales, L. (2007). Theft and taxes. Journal of Financial Economics, 84(3), 591-623. https://doi.org/10.1016/j.jfineco.2006.05.005

Dyreng, S. D., Hanlon, M., \& Maydew, E. L. (2008). Long-Run Corporate Tax Avoidance. The Accounting Review, 83(1), 61-82.

Dyreng, S. D., Hanlon, M., \& Maydew, E. L. (2010). The effects of executives on corporate tax avoidance. Accounting Review, 85(4), 1163-1189.

https://doi.org/10.2308/accr.2010.85.4.1163

Frischmann, P. J., Shevlin, T., \& Wilson, R. (2008). Economic consequences of increasing the conformity in accounting for uncertain tax benefits. Journal of Accounting and Economics, 46(2-3), 261-278. https://doi.org/10.1016/j.jacceco.2008.08.002

Gaertner, F. B. (2014). CEO After-Tax Compensation Incentives and Corporate Tax Avoidance. Contemporary Accounting Research, 31(4), 1077-1102. https://doi.org/10.1111/19113846.12058

Gallemore, J., Gipper, B., \& Maydew, E. (2019). Banks as Tax Planning Intermediaries. Journal of Accounting Research, 57(1), 169-209. https://doi.org/10.1111/1475-679X.12246

Gallemore, J., Maydew, E. L., \& Thornock, J. R. (2014). The Reputational Costs of Tax Avoidance. Contemporary Accounting Research, 31(4), 1103-1133. https://doi.org/10.1111/1911-3846.12055

Graham, J. R., \& Tucker, A. L. (2006). Tax shelters and corporate debt policy. Journal of Financial Economics, 81(3), 563-594. https://doi.org/10.1016/j.jfineco.2005.09.002

Hamilton, B. H., \& Nickerson, J. A. (2003). Correcting for endogeneity in strategic management research.pdf. Strategic Organization, 1, 51-78.

Hanlon, M., \& Heitzman, S. (2010). A review of tax research. Journal of Accounting and Economics Economics, 50(2-3), 127-178. https://doi.org/10.1016/j.jacceco.2010.09.002

Hanlon, M., \& Slemrod, J. (2009). What does tax aggressiveness signal? Evidence from stock price reactions to news about tax shelter involvement. Journal of Public Economics, 93, 126-141. https://doi.org/10.1016/j.jpubeco.2008.09.004

Hoi, C. K., Wu, Q., \& Zhang, H. (2013). Is corporate social responsibility (CSR) associated with tax avoidance? Evidence from irresponsible CSR activities. The Accounting Review, 88(6), 2025-2059. https://doi.org/10.2308/accr-50544

Khan, M., Srinivasan, S., \& Tan, L. (2017). Institutional ownership and corporate tax avoidance: New evidence. The Accounting Review, 92(2), 101-122. https://doi.org/10.2308/accr-51529

Koenker, R. (2004). Quantile regression for longitudinal data. Journal of Multivariate Analysis, 91, 74-89. https://doi.org/10.1016/j.jmva.2004.05.006

Koenker, R., Bassett, G., \& Jan, N. (2007). Regression Quantiles. Econometrica, 46(1), 33-50.

Lanis, R., Richardson, G., Liu, C., \& McClure, R. (2018). The Impact of Corporate Tax Avoidance on Board of Directors and CEO Reputation. In Journal of Business Ethics (Vol. 
0). https://doi.org/10.1007/s10551-018-3949-4

Li, M. (2012). Using the Propensity Score Method to Estimate Causal Effects : A Review and Practical Guide. Organizational Research Methods, 00((0)), 1-39.

https://doi.org/10.1177/1094428112447816

Lobo, G. J. (2017). Accounting research in banking - A review. China Journal of Accounting Research, 10(1), 1-7. https://doi.org/10.1016/j.cjar.2016.09.003

Minnick, K., \& Noga, T. (2010). Do corporate governance characteristics influence tax management? Journal of Corporate Finance, 16(5), 703-718.

https://doi.org/10.1016/j.jcorpfin.2010.08.005

Petersen, M. A. (22AD). Estimating Standard Errors In Finance Panel Data Sets: Comparing Approaches. Review of Financial Studies, 435-480.

Rego, S. O. (2003). Tax-Avoidance Activities of U.S. Multinational Corporations.

Contemporary Accounting Research, 20(4), 805-833.

Rego, S. O., \& Wilson, R. (2012). Equity Risk Incentives and Corporate Tax Aggressiveness.

Journal of Accounting Research, 50(3), 775-810. https://doi.org/10.1111/j.1475-

679X.2012.00438.X

Shackelford and Shevlin. (2001). Empirical tax research in accounting: A discussion. Journal of Accounting and Economics, 31(1-3), 389-403. https://doi.org/10.1016/S01654101(01)00021-0

Shipman, J. E., Swanquist, Q. T., \& Whited, R. L. (2017). Propensity Score Matching in Accounting Research. ACCOUNTING REVIEW, 92(1), 213-244.

https://doi.org/10.2308/accr-51449

Slemrod, J. (2004). The Economics of Corporate Tax Selfishness. National Tax Journal, 57(4), 877-899. https://doi.org/10.17310/ntj.2004.4.06

Walter, I. (2016). Reputational risks and large international banks. Financial Markets and Portfolio Management, 30(1), 1-17. https://doi.org/10.1007/s11408-016-0264-x

Wilson, R. J. (2009). An Examination of Corporate Tax Shelter Participants. The Accounting Review, 84(3), 969-999. https://doi.org/10.2308/accr.2009.84.3.969

Zimmerman, J. (1983). Taxes and Firm size. Journal of Accounting Economics, 5, 119-149.

Appendix A. Variable measurement

This appendix explains how each variable were measured.

\begin{tabular}{|c|c|c|c|c|}
\hline Item & Variable & Proxy & Definition & Database \\
\hline \multirow[t]{2}{*}{1} & \multirow[t]{2}{*}{ Dependent } & GAAP & \multirow{2}{*}{ GAAP ETR $\frac{\text { Total income tax expense }(\text { TXT })}{\text { Pre }- \text { tax book income }(P I) \text { before special items }(S P I)}$} & \multirow[t]{2}{*}{ Compustat } \\
\hline & & ETR & & \\
\hline \multirow[t]{2}{*}{2} & Dependent & Cash ETR & \multirow{2}{*}{ Cash ETR $\frac{\text { Cash tax paid (TXPD) }}{\text { Pre - tax book income }(P I) \text { before special items (SPI) }}$} & \multirow[t]{2}{*}{ Compustat } \\
\hline & & & & \\
\hline 3 & Treatment & SOX & $\begin{array}{l}\text { This variable captures the effect of the Sarbanes-Oxley Act. If the year is } \\
\text { from } 2002 \text { to } 2018 \text {, this variable assumes a value equal to } 1 \text {; otherwise, } 0 \text {. }\end{array}$ & Compustat \\
\hline 5 & Control & Leverage & $\begin{array}{l}\text { The sum of long-term debt (DLTT) and long-term debt in current liabilities } \\
\text { (DLC) divided by total assets (AT) }\end{array}$ & Compustat \\
\hline 6 & Control & $\begin{array}{c}\text { Foreign } \\
\text { operations }\end{array}$ & $\begin{array}{l}\text { The firm has a non-missing, non-zero value for pre-tax income from foreign } \\
\text { operations (PIFO) }\end{array}$ & Compustat \\
\hline 7 & Control & Size & The natural log of total assets (AT) & Compustat \\
\hline
\end{tabular}




\begin{tabular}{|c|c|c|c|c|}
\hline 8 & Control & $\begin{array}{c}\text { Net } \\
\text { Operating } \\
\text { Loss }\end{array}$ & An indicator if the firm has a non-missing value of tax loss carry-forward & Compustat \\
(TLCF)
\end{tabular}

Table 1 - Sample selection

This table reports the composition of our sample, which consists of 110,030 firm-years in the Compustat covering the period 2000-2018.

\section{Panel A: Sample composition}

Decription

No. of observations

Full sample

Firms with Total Assets $<1$ million

Missing values GAAP ETR

Missing values size

Missing values leverage

Missing values intangibles

$\begin{array}{lr}\text { Final Sample } & \mathbf{1 1 0 , 0 3 0}\end{array}$

Panel B: Distribution of observations of financial and non-financial firms and by year

\begin{tabular}{lrrrrr} 
Year & Financial & $\mathbf{\%}$ & Non-Financial & \% & Total \\
\hline 2000 & 406 & $5 \%$ & 6,234 & $6 \%$ & 6,640 \\
2001 & 388 & $5 \%$ & 6,010 & $6 \%$ & 6,398 \\
2002 & 381 & $5 \%$ & 5,862 & $6 \%$ & 6,243 \\
2003 & 390 & $5 \%$ & 5,772 & $6 \%$ & 6,162 \\
2004 & 406 & $5 \%$ & 5,823 & $6 \%$ & 6,229 \\
2005 & 416 & $5 \%$ & 5,794 & $6 \%$ & 6,210 \\
2006 & 444 & $5 \%$ & 5,860 & $6 \%$ & 6,304 \\
2007 & 459 & $6 \%$ & 5,875 & $6 \%$ & 6,334 \\
2008 & 441 & $5 \%$ & 5,484 & $5 \%$ & 5,925 \\
2009 & 438 & $5 \%$ & 5,263 & $5 \%$ & 5,701 \\
2010 & 447 & $5 \%$ & 5,270 & $5 \%$ & 5,717 \\
2011 & 460 & $6 \%$ & 5,206 & $5 \%$ & 5,666 \\
2012 & 477 & $6 \%$ & 5,311 & $5 \%$ & 5,788 \\
2013 & 491 & $6 \%$ & 5,295 & $5 \%$ & 5,786 \\
2014 & 493 & $6 \%$ & 5,272 & $5 \%$ & 5,765 \\
2015 & 483 & $6 \%$ & 4,991 & $5 \%$ & 5,474 \\
2016 & 449 & $5 \%$ & 4,760 & $5 \%$ & 5,209 \\
2017 & 442 & $5 \%$ & 4,650 & $5 \%$ & 5,092 \\
2018 & 298 & $4 \%$ & 3,089 & $3 \%$ & 3,387 \\
\hline Total & $\mathbf{8 , 2 0 9}$ & $\mathbf{1 0 0 \%}$ & $\mathbf{1 0 1 , 8 2 1}$ & $\mathbf{1 0 0 \%}$ & $\mathbf{1 1 0 , 0 3 0}$
\end{tabular}


Panel C: Industry distribution of sample firm-years

\begin{tabular}{clcc} 
2-Digit NAICS Industry & Industry & $\begin{array}{c}\text { No. of } \\
\text { Observations }\end{array}$ & $\begin{array}{c}\text { \% } \\
\end{array}$ \\
\hline 11 & Agriculture, Forestry, Fishing and Hunting & 423 & $0.4 \%$ \\
21 & Mining, Quarrying, and Oil and Gas Extraction & 14,986 & $13.6 \%$ \\
22 & Utilities & 2,781 & $2.5 \%$ \\
23 & Construction & 1,534 & $1.4 \%$ \\
$31-33$ & Manufacturing & 42,707 & $38.8 \%$ \\
42 & Wholesale Trade & 3,244 & $2.9 \%$ \\
$44-45$ & Retail Trade & 4,255 & $3.9 \%$ \\
$48-49$ & Transportation and Warehousing & 3,256 & $3.0 \%$ \\
51 & Information & 12,025 & $10.9 \%$ \\
52 & Finance and Insurance & 8,209 & $7.5 \%$ \\
53 & Real Estate and Rental and Leasing & 3,219 & $2.9 \%$ \\
54 & Professional, Scientific, and Technical Services & 4,587 & $4.2 \%$ \\
55 & Management of Companies and Enterprises & 0 & $0.0 \%$ \\
56 & Administrative and Support and Waste Management and Remediation & 2,210 & $2.0 \%$ \\
61 & Educational Services & 550 & $0.5 \%$ \\
62 & Health Care and Social Assistance & 1,703 & $1.5 \%$ \\
71 & Arts, Entertainment, and Recreation & 779 & $0.7 \%$ \\
72 & Accommodation and Food Services & 1,787 & $1.6 \%$ \\
81 & Other Services (except Public Administration) & 1,775 & $1.6 \%$ \\
\hline
\end{tabular}

\section{Table 2 - Descriptive statistics}

Our sample consists of 110,030 firm-years from Compustat covering the period 2000-2018. This table presents the descriptive statistics. The tax avoidance measures are GAAP ETR and CASH ETR. See the Appendix A for variable measurement.

\begin{tabular}{lcccccccc}
\hline Variables & N & Mean & SD & Min & P25 & P50 & P75 & Max \\
\hline GAAP ETR & 110,030 & 0.14 & 0.52 & -2.48 & 0.00 & 0.15 & 0.34 & 2.21 \\
CASH ETR & 86,803 & 0.14 & 0.38 & -1.50 & 0.00 & 0.09 & 0.27 & 1.92 \\
Finance & 110,030 & 0.07 & 0.26 & 0.00 & 0.00 & 0.00 & 0.00 & 1.00 \\
R\&D & 110,030 & 0.32 & 1.84 & 0.00 & 0.00 & 0.00 & 0.04 & 11.23 \\
Leverage & 110,030 & 0.19 & 0.20 & 0.00 & 0.00 & 0.15 & 0.32 & 0.75 \\
Foreign Operations & 110,030 & 0.31 & 0.46 & 0.00 & 0.00 & 0.00 & 1.00 & 1.00 \\
Size & 110,030 & 5.64 & 2.48 & 0.69 & 3.80 & 5.56 & 7.37 & 11.60 \\
Net Operating Loss & 110,030 & 0.70 & 0.46 & 0.00 & 0.00 & 1.00 & 1.00 & 1.00 \\
Intangibles to total assets & 110,030 & 0.14 & 0.19 & 0.00 & 0.00 & 0.04 & 0.22 & 0.77 \\
Gross PPE to total assets & 110,030 & 0.50 & 0.44 & 0.00 & 0.13 & 0.37 & 0.79 & 1.96 \\
ROA & 110,030 & 0.02 & 0.29 & -1.46 & -0.03 & 0.08 & 0.14 & 0.41 \\
Market to Book & 110,030 & 3.76 & 7.57 & 0.17 & 1.07 & 1.90 & 3.55 & 44.34 \\
\hline
\end{tabular}


Table 3 - Pearson (below) and Spearman (above) correlations of tax avoidance measures

This table presents the results of Pearson and Spearmn correlations of the variables.

\begin{tabular}{|c|c|c|c|c|c|c|c|c|c|c|c|c|c|}
\hline & Variables & 1 & 2 & 3 & 4 & 5 & 6 & 7 & 8 & 9 & 10 & 11 & 12 \\
\hline 1 & GAAP ETR & 1 & $0.4302 *$ & $0.0269 *$ & $-0.1662 *$ & $0.0506^{*}$ & $0.0108 *$ & $0.2045^{*}$ & -0.0013 & $0.0627 *$ & $0.0714 *$ & $0.3846 *$ & -0.0046 \\
\hline 2 & CASH ETR & $0.1627^{*}$ & 1 & $0.0444 *$ & $-0.0937 *$ & $0.0229 *$ & $0.1208 *$ & $0.2930 *$ & $0.0295 *$ & $0.1602 *$ & $-0.0074 *$ & $0.4921 *$ & $0.0811^{*}$ \\
\hline 3 & Finance & $0.0089 *$ & $0.0203 *$ & 1 & $-0.1962 *$ & $-0.0204 *$ & $-0.1013 *$ & $0.1172 *$ & $0.0105^{*}$ & $-0.0943^{*}$ & $-0.3454 *$ & $-0.0866^{*}$ & $-0.0881^{*}$ \\
\hline 4 & $\mathrm{R} \& \mathrm{D}$ & $-0.0412 *$ & $-0.0419 *$ & $-0.0448 *$ & 1 & $-0.2411 *$ & $0.3112^{*}$ & $-0.1022 *$ & $0.0195 *$ & $0.1690 *$ & $-0.2068 *$ & $-0.1128 *$ & $0.2130 *$ \\
\hline 5 & Leverage & $0.0213 *$ & $-0.0094 *$ & 0.0017 & $-0.0889 *$ & 1 & -0.0014 & $0.3814^{*}$ & $-0.0376^{*}$ & $0.1950^{*}$ & $0.2384^{*}$ & $0.1178 *$ & $-0.0249 *$ \\
\hline 6 & Foreign Operations & $0.0228 *$ & $0.0522 *$ & $-0.0982 *$ & $-0.0432 *$ & 0.0014 & 1 & $0.2694^{*}$ & $0.0433 *$ & $0.2464^{*}$ & $-0.0702 *$ & $0.1124 *$ & $0.1236^{*}$ \\
\hline 7 & Size & $0.1141 *$ & $0.1236^{*}$ & $0.1092 *$ & $-0.1223 *$ & $0.3425 *$ & $0.2767^{*}$ & 1 & $-0.0127 *$ & $0.2738 *$ & $0.0881^{*}$ & $0.3291 *$ & $0.0493 *$ \\
\hline 8 & NOL & -0.0055 & $0.0187 *$ & $0.0157 *$ & $0.0111 *$ & $-0.0294 *$ & $0.0372 *$ & $-0.0186^{*}$ & 1 & $0.0225 *$ & $-0.0563 *$ & $0.0251 *$ & $0.0393 *$ \\
\hline 9 & Intangibles & $0.0177 *$ & $0.0456^{*}$ & $-0.0824 *$ & $-0.0345^{*}$ & $0.1628 *$ & $0.1860 *$ & $0.1983 *$ & $0.0208 *$ & 1 & $-0.2537 *$ & $0.1798^{*}$ & $0.1356^{*}$ \\
\hline 10 & PPE & $0.0314^{*}$ & $-0.0165^{*}$ & $-0.2619 *$ & $-0.1139 *$ & $0.2074 *$ & $-0.0921 *$ & $0.0921 *$ & $-0.0455^{*}$ & $-0.2920 *$ & 1 & $0.2214^{*}$ & $-0.0860 *$ \\
\hline 11 & ROA & $0.1215^{*}$ & $0.1612 *$ & $0.0404 *$ & $-0.3349 *$ & $0.1729 *$ & $0.1560 *$ & $0.4555^{*}$ & -0.003 & $0.1134 *$ & $0.1323 *$ & 1 & $0.2444 *$ \\
\hline 12 & Market-to-Book & $-0.0263 *$ & $-0.0251 *$ & $-0.0485^{*}$ & $0.0772 *$ & $0.0503 *$ & -0.0039 & $-0.1515^{*}$ & $0.0215^{*}$ & -0.0009 & $-0.0802 *$ & $-0.2098 *$ & 1 \\
\hline
\end{tabular}


Table 4 - Difference of Means

This table presentes the descriptive statistics of tax avoidance measures separately for financial and non-financial firms. The last column reports the $\mathrm{p}$-values for the difference between financial and non-financial firms in means. $\mathrm{T}$ test (Wilcoxon rank tests) are used to test the difference in means. $* * * p<0.01, * * p<0.05, * p<0.10$

\begin{tabular}{|c|c|c|c|c|c|c|c|}
\hline \multirow[b]{2}{*}{ Variables } & \multicolumn{3}{|c|}{ Financial } & \multicolumn{3}{|c|}{ Non-Financial } & \multirow[b]{2}{*}{ Difference of means } \\
\hline & Mean & P50 & SD & Mean & P50 & SD & \\
\hline GAAP ETR & 0.16 & 0.18 & 0.44 & 0.14 & 0.15 & 0.53 & $-0.017 * *$ \\
\hline CASH ETR & 0.17 & 0.14 & 0.37 & 0.14 & 0.08 & 0.38 & $-0.029 * * *$ \\
\hline $\mathrm{R} \& \mathrm{D}$ & 0.03 & 0.00 & 0.50 & 0.34 & 0.00 & 1.90 & $0.313 * * *$ \\
\hline Leverage & 0.19 & 0.09 & 0.23 & 0.19 & 0.15 & 0.19 & -0.001 \\
\hline Foreign Operations & 0.15 & 0.00 & 0.36 & 0.33 & 0.00 & 0.47 & $0.173 * * *$ \\
\hline Size & 6.60 & 6.50 & 2.79 & 5.56 & 5.48 & 2.44 & $-1.031 * * *$ \\
\hline Net Operating Loss & 0.73 & 1.00 & 0.45 & 0.70 & 1.00 & 0.46 & $-0.027 * * *$ \\
\hline Intangibles to total assets & 0.09 & 0.00 & 0.17 & 0.15 & 0.05 & 0.20 & $0.060 * * *$ \\
\hline Gross PPE to total assets & 0.09 & 0.02 & 0.21 & 0.53 & 0.42 & 0.44 & $0.437 * * *$ \\
\hline ROA & 0.04 & 0.04 & 0.17 & 0.00 & 0.08 & 0.30 & $-0.044 * * *$ \\
\hline Market to Book & 2.47 & 1.19 & 4.87 & 3.87 & 1.97 & 7.74 & $1.397 * * *$ \\
\hline
\end{tabular}


Table 5 - Tax avoidance of financial and non-financial firms

This table presents the results from regressing tax avoidance on financial and non-financial firms. All variables are defined in the Appendix A. We standardize all the independent variables to facilitate comparison of the coefficients. The standard errors are clustered at the year and NAICS 3-digit industry levels.

\begin{tabular}{lcc}
\hline Variables & $(1)$ & $(2)$ \\
Finance & GAAP ETR & CASH ETR \\
R\&D & $\mathbf{0 . 0 0 0}$ & $\mathbf{0 . 0 0 8}$ \\
& {$[-\mathbf{0 . 0 5 2}]$} & {$[\mathbf{1 . 1 2 5}]$} \\
Leverage & $-0.001^{* *}$ & $0.001^{*}$ \\
Foreign Operations & {$[-2.132]$} & {$[1.806]$} \\
& $-0.074^{* * *}$ & $-0.099^{* * *}$ \\
Size & {$[-4.190]$} & {$[-10.803]$} \\
& $-0.015^{* * *}$ & 0.005 \\
NOL & {$[-3.381]$} & {$[1.575]$} \\
& $0.018^{* * *}$ & $0.013^{* * * *}$ \\
Intangibles & {$[12.089]$} & {$[15.368]$} \\
& -0.004 & $0.013^{* *}$ \\
Gross PPE & {$[-0.574]$} & {$[2.512]$} \\
& 0.008 & $0.036^{* * *}$ \\
ROA & {$[0.409]$} & {$[3.567]$} \\
& $0.021^{* *}$ & $-0.016^{* *}$ \\
Market to Book & {$[2.765]$} & {$[-2.452]$} \\
& $0.156^{* * *}$ & $0.222^{* * * *}$ \\
Constant & {$[18.990]$} & {$[32.637]$} \\
& $0.001^{*}$ & $0.001 * * *$ \\
Observations & {$[1.830]$} & {$[3.740]$} \\
Year dummies & $0.045^{* * *}$ & $0.058^{* * * *}$ \\
Cluster Firm FE x Year & {$[4.140]$} & {$[8.529]$} \\
Adjusted R-squared & & \\
R-Squared & 110,030 & 86,803 \\
& Yes & Yes \\
& Yes & Yes \\
& 0.0200 & 0.0344 \\
\end{tabular}

Robust t-statistics in brackets

$* * * \mathrm{p}<0.01, * * \mathrm{p}<0.05, * \mathrm{p}<0.10$ 
Table 6 - Quantile Regression GAAP ETR

This table shows the results of the Quantile regression both the GAAP ETR and CASH ETR.

\begin{tabular}{|c|c|c|c|c|c|c|c|c|c|c|c|c|}
\hline \multirow{3}{*}{ Variables } & \multicolumn{6}{|c|}{ GAAP ETR (1) } & \multicolumn{6}{|c|}{ CASH ETR (2) } \\
\hline & \multicolumn{2}{|c|}{ Quantile 0.10} & \multicolumn{2}{|c|}{ Quantile 0.50} & \multicolumn{2}{|c|}{ Quantile 0.90} & \multicolumn{2}{|l|}{ Quantile 0.10} & \multicolumn{2}{|c|}{ Quantile 0.50} & \multicolumn{2}{|c|}{ Quantile 0.90} \\
\hline & Coef. & p-value & Coef. & $\mathrm{p}$-value & Coef. & p-value & Coef. & p-value & Coef. & p-value & Coef. & $\mathrm{p}$-value \\
\hline Finance & 0.0135 & $0.000 * * *$ & -0.0162 & $0.000 * * *$ & -0.0089 & $0.023^{* *}$ & -0.0019 & 0.633 & 0.0101 & $0.002 * *$ & 0.0059 & 0.370 \\
\hline$R \& D$ & 0.0005 & 0.000 & -0.0021 & 0.000 & -0.0064 & 0.000 & 0.0044 & 0.000 & 0.0008 & 0.057 & -0.0051 & 0.000 \\
\hline Leverage & -0.1253 & 0.000 & -0.0949 & 0.000 & 0.0782 & 0.000 & -0.1028 & 0.000 & -0.1304 & 0.000 & 0.0152 & 0.209 \\
\hline Foreign Operations & -0.0761 & 0.000 & 0.0019 & 0.334 & 0.005 & 0.168 & -0.0278 & 0.000 & 0.0177 & 0.000 & 0.012 & 0.012 \\
\hline Size & 0.0082 & 0.000 & 0.0274 & 0.000 & 0.0023 & 0.000 & 0.0091 & 0.000 & 0.0188 & 0.000 & 0.0041 & 0.003 \\
\hline NOL & 0.0035 & 0.068 & -0.0007 & 0.669 & -0.0039 & 0.170 & 0.0122 & 0.000 & 0.0119 & 0.000 & 0.0024 & 0.539 \\
\hline Intangibles & -0.0655 & 0.000 & 0.0681 & 0.000 & 0.0055 & 0.408 & 0.0264 & 0.000 & 0.0728 & 0.000 & -0.0186 & 0.093 \\
\hline Gross PPE & -0.0055 & 0.087 & 0.0381 & 0.000 & 0.0174 & 0.000 & -0.0094 & 0.001 & -0.0124 & 0.000 & -0.0214 & 0.004 \\
\hline $\mathrm{ROA}$ & -0.0269 & 0.000 & 0.1343 & 0.000 & 0.1964 & 0.000 & 0.1288 & 0.000 & 0.1584 & 0.000 & 0.2118 & 0.000 \\
\hline Market to Book & 0.0004 & 0.000 & 0.0009 & 0.000 & -0.0018 & 0.000 & 0.0017 & 0.000 & 0.002 & 0.000 & -0.0019 & 0.000 \\
\hline $\mathrm{N}^{\mathrm{o}}$ of observations & 110,030 & & & & & & $\mathrm{~N}^{\circ}$ of observations & 86,803 & & & & \\
\hline 0.10 Pseudo R2 & 0.0080 & & & & & & 0.10 Pseudo R2 & 0.010 & & & & \\
\hline 0.50 Pseudo R2 & 0.0974 & & & & & & 0.50 Pseudo R2 & 0.0861 & & & & \\
\hline 0.90 Pseudo R2 & 0.0247 & & & & & & 0.90 Pseudo R2 & 0.0202 & & & & \\
\hline
\end{tabular}


Table 7 - First-stage prediction model of Propensity Score Matching (GAAP ETR)

This table presents the first-stage model used for estimating propensity scores in the setting of the effects of the Sarbanes-Oxley Act (SOX) on tax avoidance. Here we use the proxy GAAP ETR. This model is estimated using probit regression. All variables are defined in the Appendix A.

\begin{tabular}{|c|c|}
\hline Variables & $\begin{array}{c}(1) \\
\text { SOX }\end{array}$ \\
\hline GAAP ETR & $\begin{array}{c}-0.108 * * * \\
{[-0.010]}\end{array}$ \\
\hline Finance & $\begin{array}{c}0.195 * * * \\
{[0.021]}\end{array}$ \\
\hline$R \& D$ & $\begin{array}{c}-0.003 \\
{[0.002]}\end{array}$ \\
\hline Leverage & $\begin{array}{c}-0.634 * * * \\
{[0.027]}\end{array}$ \\
\hline Foreign Operations & $\begin{array}{c}0.224 * * * * \\
{[0.012]}\end{array}$ \\
\hline Size & $\begin{array}{c}0.070^{* * * *} \\
{[0.025]}\end{array}$ \\
\hline NOL & $\begin{array}{c}0.225^{* * * *} \\
{[0.010]}\end{array}$ \\
\hline Intangibles & $\begin{array}{c}0.332 * * * \\
{[0.029]}\end{array}$ \\
\hline Gross PPE & $\begin{array}{c}0.167 * * * * \\
{[0.013]}\end{array}$ \\
\hline ROA & $\begin{array}{c}-0.132 * * * \\
{[0.020]}\end{array}$ \\
\hline Market to Book & $\begin{array}{c}0.006 * * * * \\
{[0.007]}\end{array}$ \\
\hline Constant & $\begin{array}{c}0.006 * * * * \\
{[0.007]}\end{array}$ \\
\hline Observations & 110,030 \\
\hline Year dummies & Yes \\
\hline Cluster Firm FE x Year & Yes \\
\hline Pseudo R-Squared & 0.0329 \\
\hline
\end{tabular}

Standard error in brackets

$* * * \mathrm{p}<0.01, * * \mathrm{p}<0.05, * \mathrm{p}<0.10$ 
Table 8 - Sample of Propensity Score Matching (GAAP ETR)

This table presents the composition of sample treated and non-treated in the model used for estimating propensity scores in the setting of the effects of the Sarbanes-Oxley Act (SOX) on tax avoidance. Here we use the proxy GAAP ETR.

\begin{tabular}{lccccc}
\hline & Obs & Mean & SD & Min & Max \\
\hline Full Sample & 110,030 & 0.8815 & 0.0503 & 0.5821 & 0.9967 \\
Sarbanes-Oxley Act (SOX) $=0$ & 13,038 & 0.8599 & 0.0537 & 0.5962 & 0.9936 \\
Sarbanes-Oxley Act (SOX) $=1$ & 96,992 & 0.8844 & 0.0492 & 0.5821 & 0.9967 \\
\hline
\end{tabular}

Table 09 - Matching - Sarbanes-Oxley Act (SOX): GAAP ETR

This table presents the results of the propensity score matching nearest neighbor: 1 neighbor, 5 neighbors and 10 neighbors with replacement of the effects of the Sarbanes-Oxley Act (SOX) on tax avoidance. Here we use the proxy GAAP ETR.

\begin{tabular}{lccc}
\hline & \multicolumn{3}{c}{$\begin{array}{c}\text { Nearest neighbor (1 neighbor) } \\
\text { With replacement }\end{array}$} \\
\hline Sample & Treated & Difference & t-stat \\
\hline Unmatched & 0.1348 & -0.0352 & -7.26 \\
ATT & 0.1348 & -0.0049 & -0.08 \\
n untreated & & & 13,038 \\
n treated & & & 96,992 \\
TOTAL & & & $\mathbf{1 1 0 , 0 3 0}$ \\
\cline { 2 - 3 }
\end{tabular}

\begin{tabular}{ccc}
\multicolumn{3}{c}{$\begin{array}{c}\text { Nearest neighbor (5 neighbors) } \\
\text { With replacement }\end{array}$} \\
\hline Treated & Difference & t-stat \\
\hline 0.1348 & -0.0352 & -7.26 \\
0.1348 & -0.0036 & -0.66 \\
& & 13,038 \\
& & 96,992 \\
& & $\mathbf{1 1 0 , 0 3 0}$ \\
\hline
\end{tabular}

\begin{tabular}{ccc}
\multicolumn{3}{c}{ Nearest neighbor (10 neighbors) } \\
With replacement \\
\hline Treated & Difference & t-stat \\
\hline 0.1348 & -0.0352 & -7.26 \\
0.1348 & -0.003 & -0.57 \\
& & 13,038 \\
& & 96,992 \\
& & $\mathbf{1 1 0 , 0 3 0}$ \\
\hline
\end{tabular}


Table 10 - First-stage prediction model of Propensity Score Matching (CASH ETR)

This table presents the first-stage model used for estimating propensity scores in the setting of the effects of the Sarbanes-Oxley Act (SOX) on tax avoidance. Here we use the proxy CASH ETR. This model is estimated using probit regression. All variables are defined in the Appendix A.

\begin{tabular}{|c|c|}
\hline & $(2)$ \\
\hline Variables & SOX \\
\hline CASH ETR & $\begin{array}{c}-0.105 * * * \\
{[0.014]}\end{array}$ \\
\hline Finance & $\begin{array}{l}0.114 * * * \\
{[0.024]}\end{array}$ \\
\hline$R \& D$ & $\begin{array}{c}0.001 \\
{[0.005]}\end{array}$ \\
\hline Leverage & $\begin{array}{c}-0.766 * * * * \\
{[0.031]}\end{array}$ \\
\hline Foreign Operations & $\begin{array}{c}0.213 * * * \\
{[0.013]}\end{array}$ \\
\hline Size & $\begin{array}{c}0.087 * * * \\
{[0.002]}\end{array}$ \\
\hline NOL & $\begin{array}{c}0.190 * * * \\
{[0.012]}\end{array}$ \\
\hline Intangibles & $\begin{array}{c}0.490 * * * \\
{[0.034]}\end{array}$ \\
\hline Gross PPE & $\begin{array}{c}0.169 * * * \\
{[0.015]}\end{array}$ \\
\hline ROA & $\begin{array}{c}-0.205^{* * * *} \\
{[0.027]}\end{array}$ \\
\hline Market to Book & $\begin{array}{c}0.010 * * * \\
{[0.001]}\end{array}$ \\
\hline Constant & $\begin{array}{c}0.480 * * * \\
{[0.019]}\end{array}$ \\
\hline Observations & 86,803 \\
\hline Year dummies & Yes \\
\hline Cluster Firm FE x Year & Yes \\
\hline Pseudo R-Squared & 0.0410 \\
\hline
\end{tabular}

Standard error in brackets

*** $\mathrm{p}<0.01, * * \mathrm{p}<0.05, * \mathrm{p}<0.10$ 
Table 11 - Sample of Propensity Score Matching (CASH ETR)

This table presents the composition of sample treated and non-treated in the model used for estimating propensity scores in the setting of the effects of the Sarbanes-Oxley Act (SOX) on tax avoidance. Here we use the proxy CASH ETR.

\begin{tabular}{lccccc}
\hline & Obs & Mean & SD & Min & Max \\
\hline Full Sample & 86,803 & 0.8839 & 0.0557 & 0.5170 & 0.9997 \\
Sarbanes-Oxley Act (SOX) $=0$ & 10,078 & 0.857 & 0.0607 & 0.5808 & 0.9996 \\
Sarbanes-Oxley Act (SOX) $=1$ & 76,725 & 0.8874 & 0.0541 & 0.5170 & 0.9976 \\
\hline
\end{tabular}

Table 12 - Matching - Sarbanes-Oxley Act (SOX): CASH ETR

This table presents the results of the propensity score matching nearest neighbor: 1 neighbor, 5 neighbors and 10 neighbors with replacement of the effects of the Sarbanes-Oxley Act (SOX) on tax avoidance. Here we use the proxy CASH ETR.

\begin{tabular}{|c|c|c|c|c|c|c|c|c|c|}
\hline \multirow[b]{2}{*}{ Sample } & \multicolumn{3}{|c|}{$\begin{array}{c}\text { Nearest neighbor (1 neighbor) With } \\
\text { replacement }\end{array}$} & \multicolumn{3}{|c|}{$\begin{array}{c}\text { Nearest neighbor ( } 5 \text { neighbors) } \\
\text { With replacement }\end{array}$} & \multicolumn{3}{|c|}{$\begin{array}{c}\text { Nearest neighbor (10 neighbors) } \\
\text { With replacement }\end{array}$} \\
\hline & Treated & Difference & t-stat & Treated & Difference & t-stat & Treated & Difference & t-stat \\
\hline Unmatched & 0.1388 & -0.009 & -2.27 & 0.1388 & -0.0090 & -2.27 & 0.1388 & -0.0090 & -2.27 \\
\hline ATT & 0.1388 & 0.0039 & 0.63 & 0.1388 & 0.0052 & 0.63 & & 0.0047 & 0.92 \\
\hline n untreated & & & 10,078 & & & 10,078 & & & 10,078 \\
\hline $\mathrm{n}$ treated & & & 76,725 & & & 76,725 & & & 76,725 \\
\hline TOTAL & & & 86,803 & & & 86,803 & & & 86,803 \\
\hline
\end{tabular}


Figure 01 - Propensity Score Matching graph: Sarbanes-Oxley Act (SOX): GAAP ETR

This graph presents the results of the propensity score matching of the Sarbanes-Oxley Act (SOX) on tax avoidance. Here we use the proxy GAAP ETR.

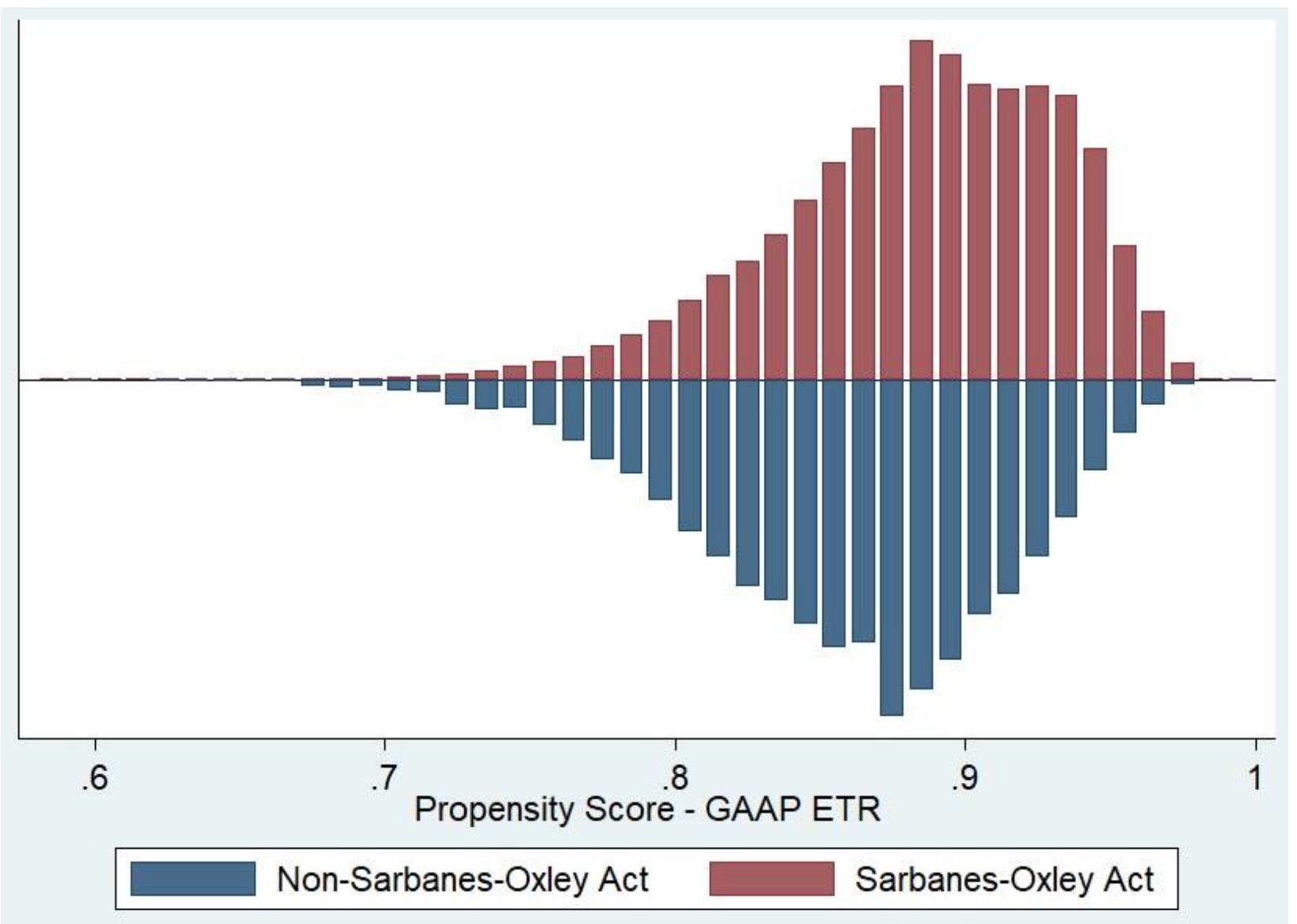


Figure 02 - Graph before matching: Sarbanes-Oxley Act (SOX): GAAP ETR

This graph presents the results before matching. Here we use the proxy GAAP ETR.

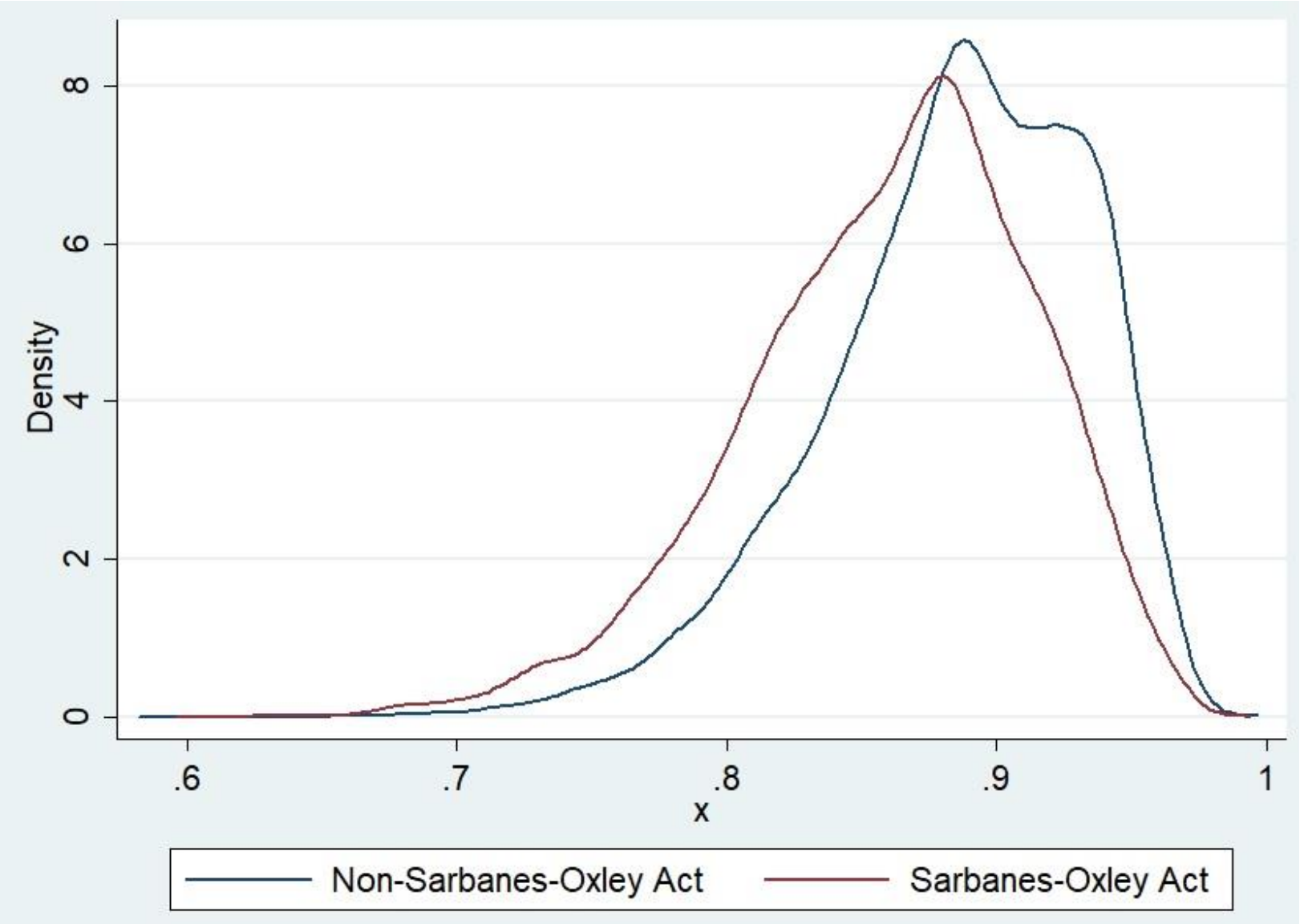


Figure 03 - Graph after matching: Sarbanes-Oxley Act (SOX): GAAP ETR

This graph presents the results after matching. Here we use the proxy GAAP ETR.

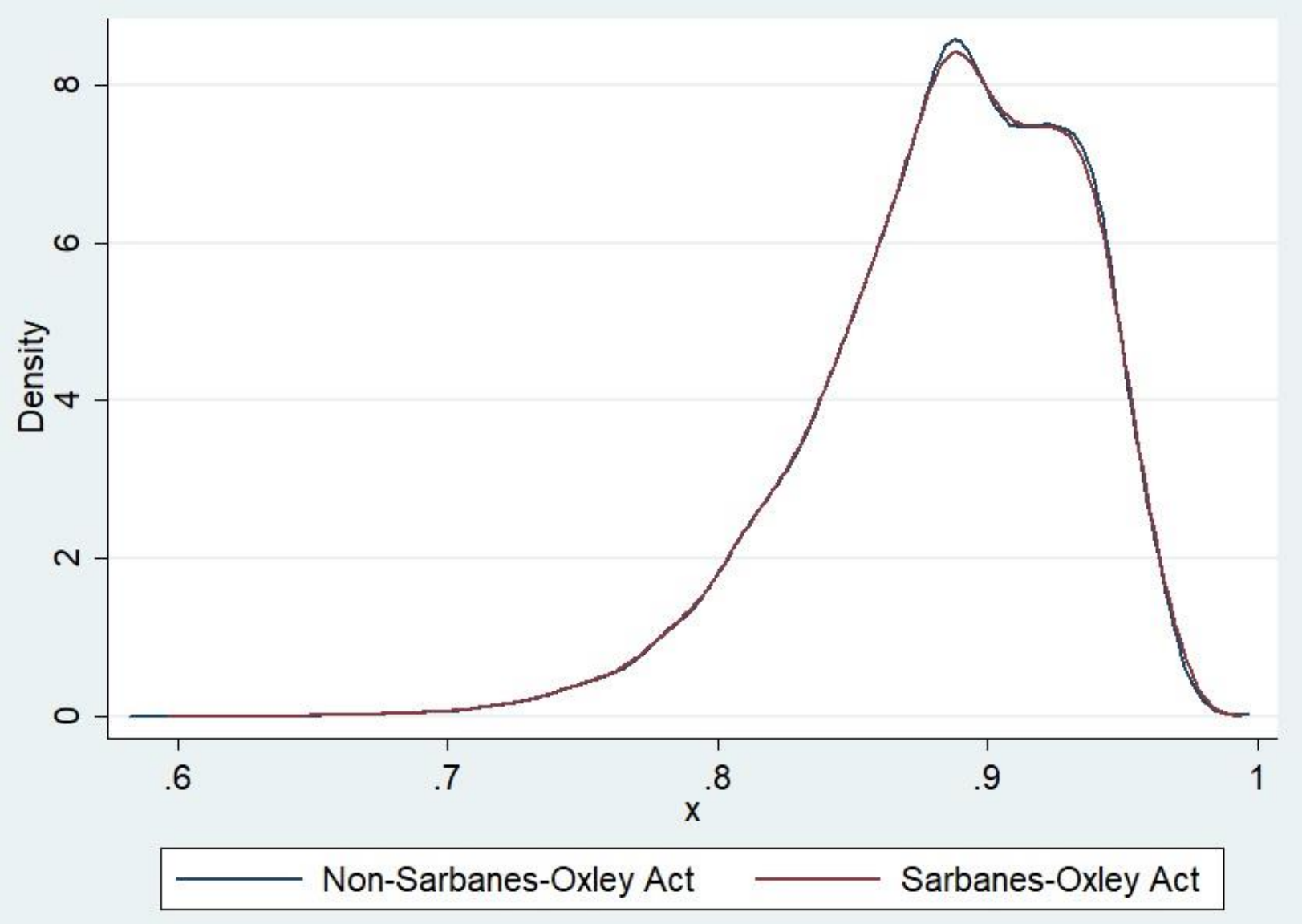


Figure 04 - Propensity Score Matching graph: Sarbanes-Oxley Act (SOX): CASH ETR

This graph presents the results of the propensity score matching of the Sarbanes-Oxley Act (SOX) on tax avoidance. Here we use the proxy CASH ETR.

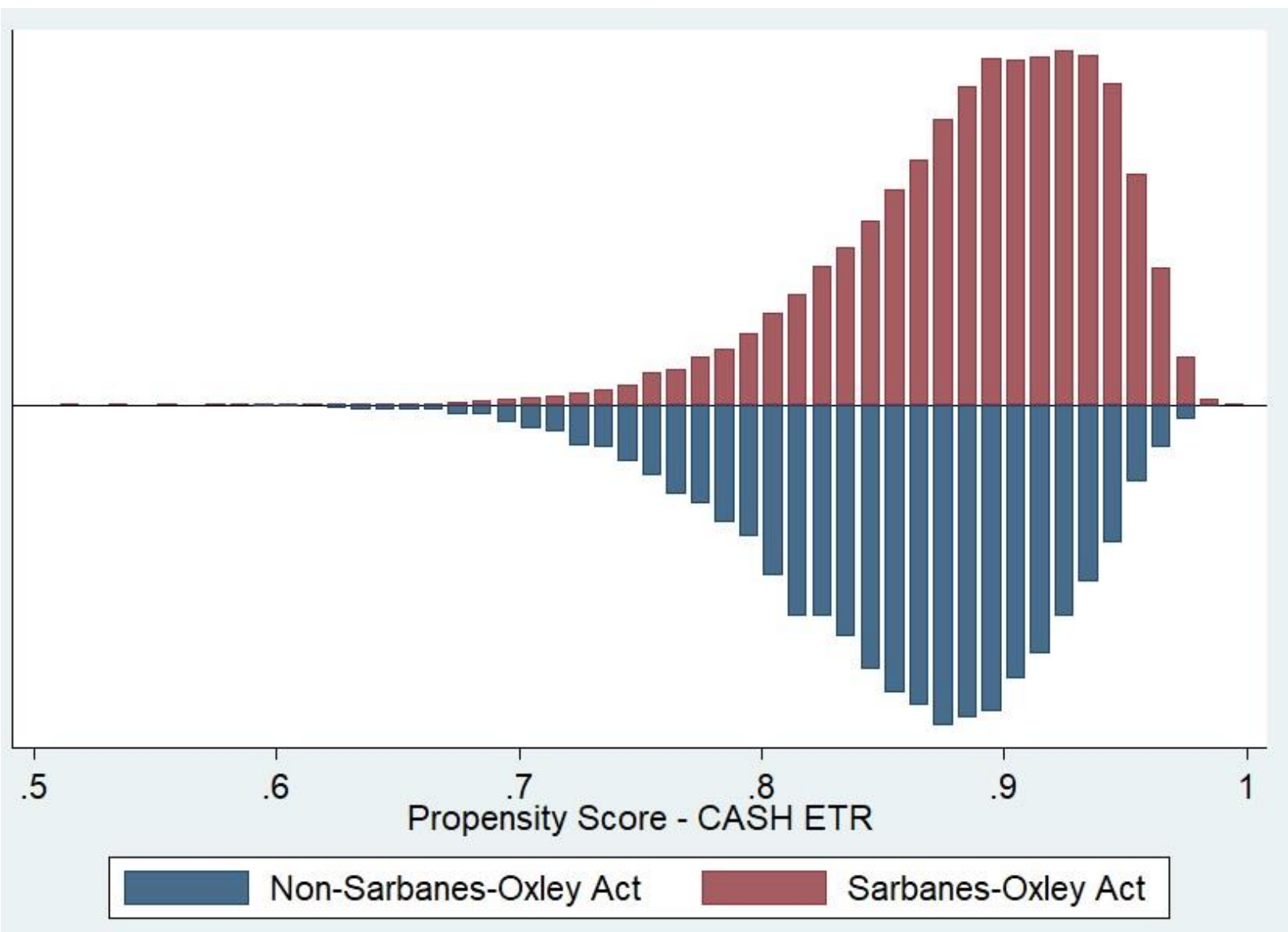


Figure 05 - Graph before matching: Sarbanes-Oxley Act (SOX): CASH ETR

This graph presents the results before matching. Here we use the proxy CASH ETR.

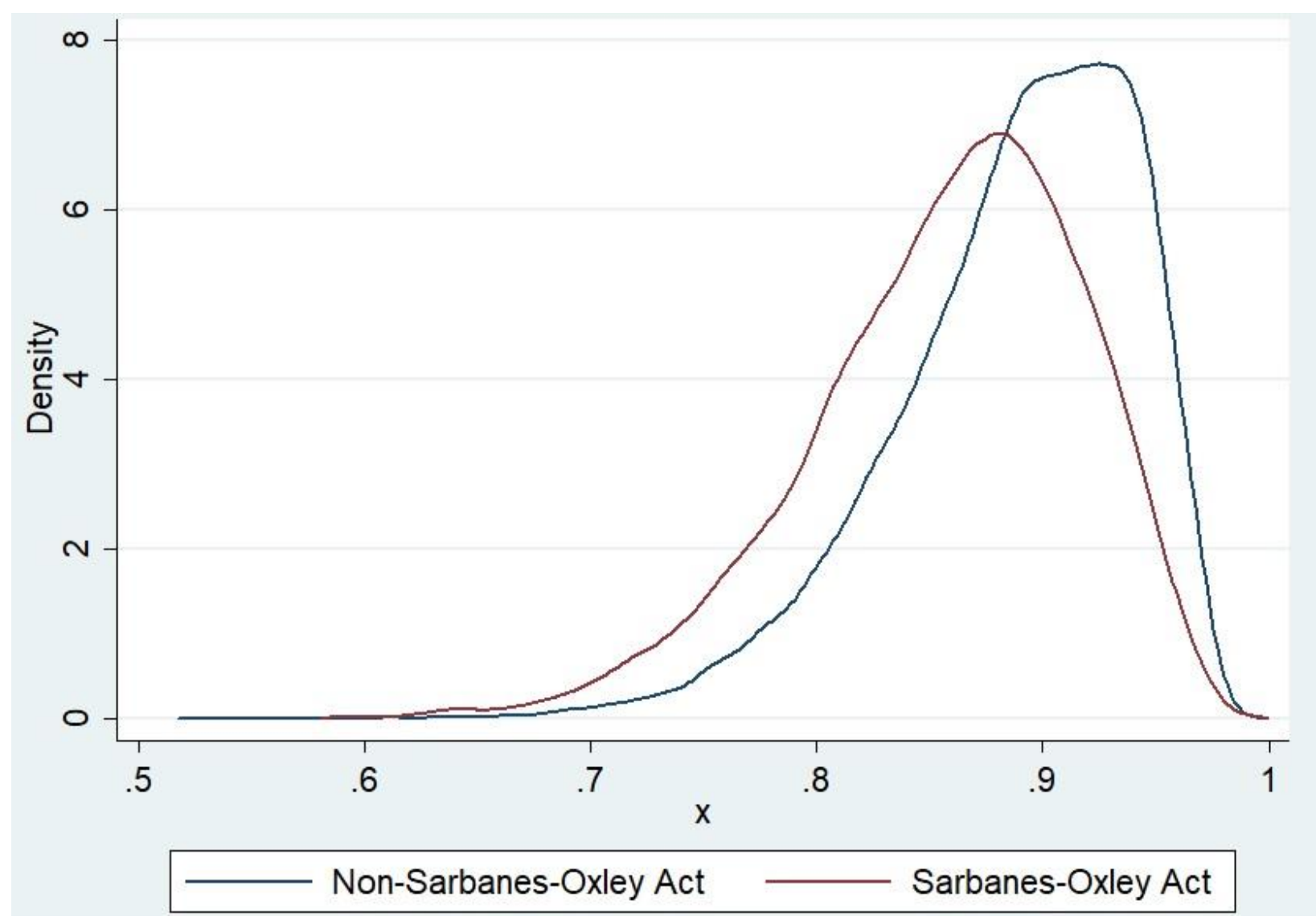


Figure 06 - Graph after matching: Sarbanes-Oxley Act (SOX): CASH ETR

This graph presents the results after matching. Here we use the proxy CASH ETR.

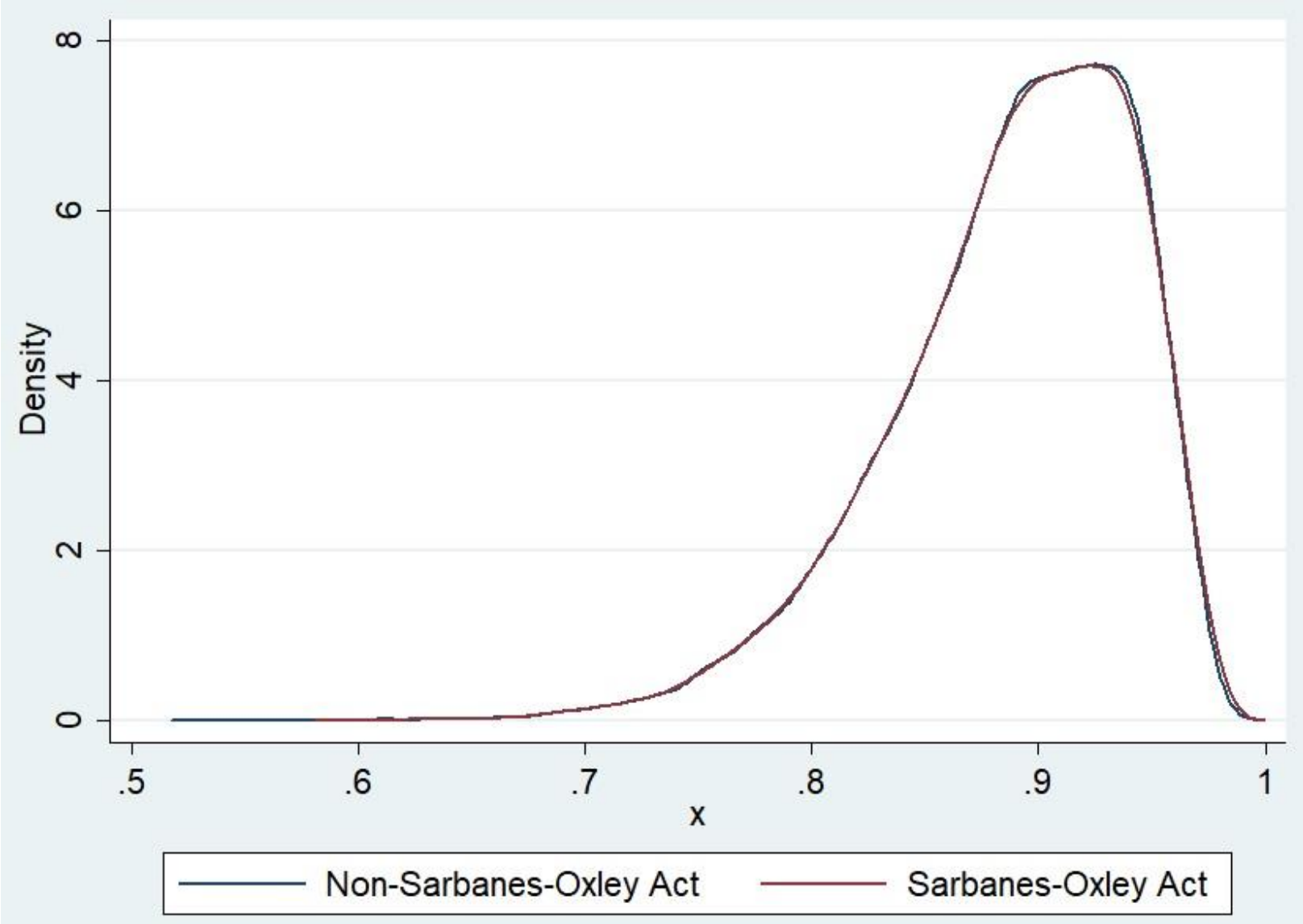

